ANSPACH, Mark R. Édipo mimético. Trad. Ana Lúcia Costa. São Paulo: É Realizações, 2012.

\title{
HÁ IMUNDÍCIES SOBRE TUA CABEÇA, ÉDIPO!
}

\section{Diego Gomes do Valle \\ Doutor em Teoria e História Literária (UNICAMP) \\ diegouab@gmail.com}

Italo Calvino, nas famosas assertivas a respeito dos clássicos, diz em uma delas que: “Os clássicos são livros que, quanto mais pensamos conhecer por ouvir dizer, quando são lidos de fato mais se revelam novos, inesperados, inéditos" (CALVINO, 1993, p. 12). Inegavelmente, a leitura de Édipo Rei feita por Mark Anspach confirma o dizer de Calvino, pois consegue, por meio da teoria mimética girardiana, escapar do Édipo freudiano ou do anti-Édipo deleuziano. O próprio René Girard, no prefácio da obra ora resenhada, reconhece a originalidade e a atualidade de tal leitura: "O Édipo que ele [Mark Anspach] nos dá aqui não é aquele do famoso complexo, mas, pelo contrário, aquele que o complexo oculta. É um Édipo dos nossos tempos, um Édipo preso, como nós, nas simetrias ofuscantes do desejo mimético" (GIRARD in ANSPACH, 2012, p. 11). Novamente, Calvino complementa com o seguinte corolário: "É clássico aquilo que persiste como rumor mesmo onde predomina a atualidade mais incompatível" (CALVINO, 1993, p. 15). Abaixo, discorreremos a respeito de tal atualidade e seu vínculo com a teoria do desejo mimético.

Cumpre dizer que a obra de Anspach faz parte da "Biblioteca René Girard", um projeto da editora É Realizações, coordenado pelo professor e crítico João Cézar de Castro Rocha, que busca a divulgação e aprofundamento do pensamento girardiano. Para Girard, "não desejamos direta, mas indiretamente, e o alvo do nosso desejo é determinado menos por 
nós mesmos do que pelas redes tramadas pelas mediações nas quais nos envolvemos"1 (ROCHA, 2009, p. 16-7). Ligado a essa trama mimética está o fenômeno central da teoria girardiana, funcional para compreender o caso de Édipo: o bode expiatório.

No diálogo que antecede o texto de Anspach, o autor inicia com a seguinte proposição: "Todos pensam saber quem é Édipo: ele matou o pai e casou com a mãe. Você, René Girard, diz: calma! Édipo foi acusado de matar o pai e casar com a mãe..." (ANSPACH, 2012, p. 19). Aos poucos, Anspach (aludindo direta e indiretamente a Girard) apresenta elementos que relativizam a pré-compreensão que todos temos da história de Sófocles e, ipso facto, desdobram a dinâmica mimética que envolve a trama do Rei de Tebas.

“A rivalidade gera a imitação, a imitação gera a rivalidade" (ANSPACH, 2012, p. 31). Essa fórmula resume o embate inicial de Édipo contra Tirésias: o cego profeta tentando iluminar o obscuro (supostamente) mundo de Édipo. O tema do duplo, ao gosto de um Borges ou um Hoffmann, aparece inusitadamente em Sófocles:

A ofensa de Tirésias - tão involuntária como a de Édipo - consiste em ter descoberto a nudez da deusa. Por ter usado mal seus olhos, é condenado a perdêlos. Agora, no tocante à peça, constatamos que Édipo se cega por meio dos alfinetes arrancados do manto de Jocasta - alfinetes que deviam esconder sua nudez. Portanto, assim como o castigo de Tirésias, o de Édipo também se aplica ao crime cometido. Édipo, portanto, perde seus olhos depois de tê-los usado mal. Sua cegueira e seus motivos tanto em Tirésias como em Édipo foram os mesmos (ANSPACH, 2012, p. 37).

O duplo gera a indistinção, a indiferenciação identitária. Da mesma forma, a peste leitmotiv da busca edipiana - cria uma crise na qual todos os que sofrem tornam-se uma massa amorfa que clama e busca um culpado. Por outro lado,

\footnotetext{
${ }^{1}$ Castro Rocha na Introdução de Mentira romântica e verdade romanesca.
} 
o tema do incesto é, em si mesmo, um grande indicador da perda das diferenças. Ao destruir a fronteira que separa os papéis de mãe e esposa, de filho e de marido, a união incestuosa mina as diferenças mais fundamentais sobre as quais repousa a ordem social (ANSPACH, 2012, p. 38).

É Tirésias o primeiro a encontrar em Édipo aquilo que o singulariza: “O fato de ser igual a seus filhos faz dele um lixo sem igual. Ninguém é tão sujo como ele" (ANSPACH, 2012, p. 40). Em uma crise de indistinção, o que se distingue é o estrangeiro, o de pés inchados. Anspach/Girard enxergam nesse momento a violência coletiva e arbitrária com que o povo de Tebas elege inequivocamente como responsável aquele que o salvou da Esfinge. Exclama Girard: "Ele é sempre um bode expiatório!" (ANSPACH, 2012, p. 21). É necessário, para que a ordem seja restabelecida, que um bode expiatório seja imolado - eis a intuição girardiana, repleta de implicações antropológicas e sociológicas.

Com relação aos elementos do enredo da peça de Sófocles, Anspach desestabiliza as linhas mestras do desfecho trágico: seria Édipo o regicida e seria ele o bebê entregue ao coríntio? Todas as testemunhas dizem que foram muitos os que agrediram Laio; ao passo que Édipo diz ter morto um velho e todos os outros - ao passo que um dos membros da comitiva de Laio sobrevive: "Todos, exceto um, não é igual a todos" (ANSPACH, 2012, p. 52). Assim, quanto ao regicídio, paira uma ambiguidade insolúvel. Com relação à identidade de Édipo, a prova é tênue e só pode ser deduzida se confiarmos plenamente na palavra de um mensageiro desconhecido, que quer uma recompensa por sua mensagem: "Então, o coríntio diz a Édipo a única coisa a dizer se ainda quiser obter uma recompensa real, ou seja, que Édipo não foi gerado em Corinto" (ANSPACH, 2012, p. 54).

Há sempre uma pré-compreensão que faz com que o leitor infira, subentenda, salte por cima das evidências, formando uma leitura em que "As sutilezas do inquérito são 
esquecidas, uma vez que a profanação do incesto faz de Édipo um culpado de todas as acusações possíveis: um bode expiatório" (ANSPACH, 2012, p. 55). Assim, o próprio Édipo se convence e assume a culpa pela peste; ou seja, assume a dor de todos para que a ordem seja restabelecida. Com Sócrates e, fundamentalmente, com Cristo, vemos o mesmo drama. Contudo, o Cristianismo é a religião que encerra, potencialmente, a dinâmica do bode expiatório ${ }^{2}$.

Assim, "Se o Édipo de Freud é um Édipo desejante, o Édipo de Girard é um Édipo mimético. Para Girard, o modelo vem em primeiro lugar; o mediador do desejo precede o objeto" (ANSPACH, 2012, p. 76). Deste modo, o drama freudiano é posterior à crise mimética pela qual todos passamos. Trata-se de uma mediação interna, como Anspach discorre, e Girard apresenta detalhadamente em seu Mentira..., a qual é mais aguda que a externa, pois a proximidade entre aquele que deseja e o modelo que media o desejo aprofunda a rivalidade violentamente: “Jocasta se torna 'a única esposa' para o Édipo mimético de Girard, não porque ela é sua mãe, mas porque é mulher de seu modelo" (ANSPACH, 2012, p. 92).

Toda a explanação de Anspach é entremeada por comparações com personagens do Velho Testamento, de George Sand, Marcel Proust e Dostoiévski, este último, inclusive, possui um livro específico de René Girard: Dostoiévski: do duplo à unidade (2011). Deste modo, o livro, no que tange à crítica literária, estabelece comparações profícuas e que merecem maiores desenvolvimentos.

Na parte final da obra, a crise mimética edipiana avança para um nível insuspeito: a rivalidade entre judeus e cristãos:

\footnotetext{
${ }^{2}$ É sabido que René Girard se converte ao Cristianismo durante a escrita de seu primeiro livro, Mentira romântica e verdade romanesca. 


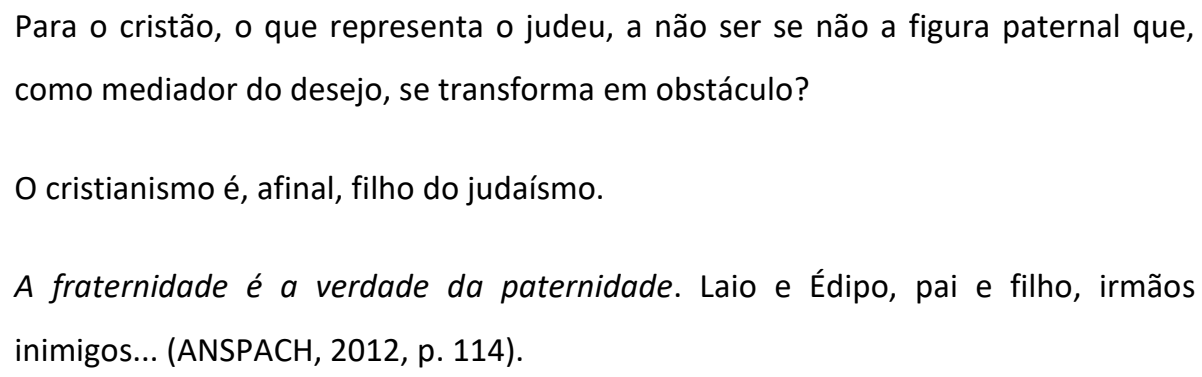

Assim, de uma leitura original da arquiconhecida peça de Sófocles Anspach, seguindo a trilha de Girard, avança para uma compreensão de fenômenos humanos profundos, antigos e complexos.

Jorge Luis Borges, em famoso texto sobre os clássicos, sustenta que o que torna clássica uma obra é justamente a atitude do leitor (como verificamos em Édipo Rei): "es un libro que las generaciones de los hombres, urgidas por diversas razones, leen con previo fervor y con una misteriosa lealtad" (BORGES, 1980, p. 303). É esta a lealdade com que apreciamos a peça de Sófocles, muitas vezes obnubilando os questionamentos que Girard e Anspach fazem. Qual será a próxima camada de sentido que o drama de Édipo nos desvelará?

Desvendemos ou seremos devorados.

\section{REFERÊNCIAS}

CALVINO, Italo. Por que ler os clássicos. Trad. Nilson Moulin. São Paulo: Companhia das Letras, 1993.

BORGES, Jorge Luis. "Sobre los clásicos". In: Prosa Completa (v. 2). Barcelona: Bruguera, 1980.

GIRARD, René. Mentira romântica e verdade romanesca. Trad. Lilia Ledon da Silva. São Paulo: É Realizações, 2009. 
Resenha aprovada em: 01 de julho de 2018. 